\title{
Expression pattern of estrogen receptor $\beta$ and its correlation with multidrug resistance in non-small cell lung cancer
}

\author{
L. HUANG ${ }^{1, *}$, T. LIU ${ }^{2, *}$, H. JI ${ }^{1}$, S. YANG ${ }^{2}$, J. SUI ${ }^{2}$, W. S. YANG ${ }^{3,4}$, G. Y. LIANG ${ }^{2, *}$, X. M. ZHANG ${ }^{5, *}$ \\ ${ }^{1}$ Department of Radiation Oncology, Jiangsu Cancer Hospital \& Jiangsu Institute of Cancer Research, Nanjing Medical University Affiliated \\ Cancer Hospital, Nanjing, Jiangsu, China; ${ }^{2}$ Key Laboratory of Environmental Medicine Engineering, Ministry of Education, School of Public \\ Health, Southeast University, Nanjing, Jiangsu, China; ${ }^{3}$ Department of Epidemiology, School of Public Health, Zhejiang University, Hangzhou, \\ Zhejiang, China; ${ }^{4}$ Department of Social Science and Public Health, School of Basic Medical Science, Jiujiang, Jiujiang, Jiangxi, China; ${ }^{5}$ Depart- \\ ment of Genetics and Molecular Biology, Jiangsu Cancer Hospital \& Jiangsu Institute of Cancer Research, Nanjing Medical University Affiliated \\ Cancer Hospital, Nanjing, Jiangsu, China
}

*Correspondence: 1125048600@qq.com; lianggeyu@163.com

"Contributed equally to this work.

Received November 20, 2018 / Accepted April 10, 2019

\begin{abstract}
The aim of this work was to determine the expression of the ER $\beta$ (estrogen receptor $\beta$ ) and multidrug resistance, namely MDR1 (P-glycoprotein, P-gp), in 152 samples of non-small cell lung cancer. The expression pattern of ER $\beta$ and MDR1 were assessed by the quantitative reverse-transcriptase polymerase chain reaction (qRT-PCR) and immunohistochemistry. We also analyzed the correlation between ER $\beta$ and MDR1 with clinical and pathological data. The co-expression pattern of ER $\beta$ and individual MDR1 proteins was assessed by correspondence analysis and chi-squared tests. In the present study, we found that patients with tumor stage I-II showed higher ER $\beta$ mRNA expression levels and decreased expression of ER $\beta$ protein with increasing tumor grade, which is opposite to MDR1 expression. In addition, an opposite co-expression pattern of ER $\beta$ and individual MDR1 proteins was also observed. In conclusion, the results can be used to better understand the expression control of MDR1 and may allow for the establishment of new cancer chemistry strategies that will control P-gp expression in NSCLC.
\end{abstract}

Key words: lung cancer, estrogen receptor $\beta, M D R 1$, -glycoprotein

Lung cancer is the cardinal cause of cancer-related deaths that threaten human health and life and its incidence and mortality are increasing worldwide [1]. Cancer statistics from 2018 estimated that lung cancer is expected to become the second most common cancer [2]. In China, lung cancer counts for $17.09 \%$ of all cancer cases with $24.35 \%$ mortality rate, and more, ranking it as the most lethal among all malignant tumor types [3]. Non-small cell lung cancer (NSCLC) includes lung squamous cell carcinoma (LUSC), lung adenocarcinoma (LUAD) and large cell carcinoma (LCLC). LUAD is one of the major histologic subtypes of lung cancer [4]. On the contrary to the LUSC, LUAD is more likely to occur in women and non-smokers [5]. Previous studies have shown that female patients with NSCLC have more favorable outcomes at different stages, suggesting the importance of gender as an independent prognostic factor for advanced NSCLC $[6,7]$. The exact cause of this condition is unclear, but the potential role of sex hormones has been suggested as a possible explanation.
Etiology of NSCLC is a complex process of multi-gene participation and multiple stages. Risk factors for the initiation and development of NSCLC have not yet been studied clearly and the key molecular induced by these factors working in the progression of this disease are left unknown, causing both lack of the special explanations for the mechanisms of cancer and the biomarkers for the early diagnosis and prevention. Over the past few decades, increased exposure to environmental endocrine disruptors chemicals (EDCs) has been associated with the development of physical illnesses, such as high susceptibility to tumorigenesis or metastatic invasion potential [8]. Lesions triggered by exposures of environmental risk factors can activate oncogenes and inactivate suppressor genes, which end up with the formation of malignant tumor. Environmental estrogen is considered to be an endocrine disruptor compound that mimics the antagonist of estrogen in the body and interferes with the physiological functions of endogenous estrogen [9]. Therefore, environmental estrogen exposure has attracted more and more 
attention. The discovery of estrogen receptor genes provided new clues about how estrogen signaling induces changes in cell function. Estrogen regulates a variety of biological processes, including cell proliferation, apoptosis, inflammation and metabolism, primarily through two classical estrogen receptor (ER) subtypes, including ER alpha (ERa) and ER beta (ER $\beta)$ [10-13]. Relative studies have shown that the expression of estrogen receptors is associated with the prognosis of NSCLC, but the roles of ER $\alpha$ and ER $\beta$ in tumor survival are complex [14-16]. Studies have shown that antiestrogen therapy can reduce the risk of death in patients with NSCLC, suggesting that endogenous and exogenous estrogen may be associated with the etiology of NSCLC $[17,18]$.

Multidrug resistance (MDR) refers to the resistance of tumor cells to various chemotherapeutic drugs and remains one of the leading causes of cancer chemotherapy inefficiency [19]. It is generally described as unresponsiveness of an organ, tissue, cell or pathological condition treated with various drugs. P-glycoprotein (P-gp) is the most frequently tested indicator. It is one of the respiratory protection components and is found in various tissues with barrier function [20]. P-gp is known as multidrug resistance protein 1 (MDR1), which localizes on both, the bronchial and bronchiolar epithelium and the alveolar macrophage plasma membrane, and has been shown to act in a removal of environmental compounds from the lungs [21]. Xu et al. evaluated whether raloxifene hydrochloride (RAL) may sensitize MDR to chemotherapy in breast cancer, especially in estrogen receptor-negative (ER-) cases, only to find that RAL could significantly sensitize ER-related MDR breast tumors to paclitaxel [22].

In the present study, we hypothesized that estrogen levels are associated with tumor multidrug resistance, with the aim of exploring the co-expression relationship between ER $\beta$ and MDR in NSCLC.

\section{Patients and methods}

Patients and tissue samples. All procedures performed in studies involving human participants were in accordance with the Ethics Committee of Jiangsu Cancer Hospital (Nanjing, Jiangsu, China). Informed consent was obtained from all individual participants. Lung tumor tissues from 76 patients with NSCLC with relative clinical information in

Table 1. Sequences of the primers used in PCR analysis.

\begin{tabular}{ll}
\hline RNAs & Primer Sequence (5' to 3') \\
\hline ER $\beta-F$ & TTCTCCTTCCTCCTACAACTG \\
ER $\beta-R$ & GATGTGATAACTGGCGATGG \\
MDR1-F & ATTTGACACCCTGGTTGGAG \\
MDR1-R & ACCACTGCTTCGCTTTCTGT \\
UGT1A1-F & AAGTGAACTCCCTGCTACCTT \\
UGT1A1-R & CCACTGGGATCAACAGTATCT \\
\hline
\end{tabular}

this study were stored in RNAlater (Ambion; Thermo Fisher Scientific, Inc., Waltham, MA, USA) and frozen at $-80^{\circ} \mathrm{C}$. Adjacent non-tumor tissues were located $>5 \mathrm{~cm}$ away from the edge of the tumor.

RNA extraction, cDNA synthesis and qRT-PCR. Expressions of ER $\beta, M D R 1$ gene and the normalization (housekeeping) gene UGT1A1 were assessed by the quantitative reverse-transcriptase polymerase chain reaction (qRT-PCR). Total RNA was extracted from tissue samples by the TRIzol reagent (Invitrogen, Carlsbad, CA, USA) and its purity was detected by NanoDrop 2000 spectrometer (Thermo Fisher Scientific, Waltham, MA, USA). RNA $(1 \mu \mathrm{g})$ was reverse transcribed into cDNA through a two-step reverse transcription reaction using the A214 reverse transcription system kit (GenStar, Beijing, China) according to the manufacturer's protocol. The primer sequences of mRNA for ER $\beta$ and MDR1 and housekeeping gene are listed in Table 1. All RNA primers were obtained from Generay Biotech Co., Ltd. (Shanghai, China). The PCR components comprised $1 \mu \mathrm{l}$ cDNA, $5 \mu \mathrm{l}$ Thunderbird SYBR qPCR mix, $0.3 \mu \mathrm{l}$ PCR primers and $3.7 \mu \mathrm{l}$ RNase-free water. Then, a two-step protocol $\left(95^{\circ} \mathrm{C}\right.$ for $1 \mathrm{~min}$, followed by 40 cycles of $95^{\circ} \mathrm{C}$ for $15 \mathrm{sec}, 60^{\circ} \mathrm{C}$ for $30 \mathrm{sec}$ and $72^{\circ} \mathrm{C}$ for $30 \mathrm{sec}$ ) was undertaken. A cycle threshold (Ct) value is determined which indicates the number of (cycled) PCR cycles until the fluorescence reaches its threshold. Ct values were normalized by subtracting the $\mathrm{Ct}$ value of the housekeeping gene (UGT1A1) from the $\mathrm{Ct}$ value of the target gene $(\Delta \mathrm{Ct})$. RNA results were calculated as $40-\Delta \mathrm{Ct}$ values, which would correlate proportionally to the mRNA expression level of the target gene [23].

Immunohistochemistry. The tissues samples ( $5 \mu \mathrm{m}$ thick sections) from another 76 patients with NSCLC obtained from the paraffin-embedded specimens were placed on glass slides. The embedded tumor tissues were routinely deparaffinized and endogenous peroxidase was quenched with $3 \%$ $\mathrm{H}_{2} \mathrm{O}_{2}$ in $1 \times \mathrm{PBS}$. Heating in sodium citrate buffer $(\mathrm{pH} 6.0)$ in a water bath at $95-100^{\circ} \mathrm{C}$ for $30 \mathrm{~min}$ accomplished the epitope retrieval. Then, the sections were incubated for 1 hour with the primary antibodies with following dilutions: 1:50 of antiER $\beta$ (Dako; Agilent Technologies, Inc., Santa Clara, CA, USA), 1:100 of anti-P-gp (Dako; Agilent Technologies, Inc., Santa Clara, CA, USA). After that, the slides were washed twice with $1 \mathrm{x}$ PBS (5 min per wash) and incubated with the secondary antibody solution for $30 \mathrm{~min}$ at room temperature. Negative controls omitted primary antibodies as well as the use of isotype control antibodies. Visualization of $\mathrm{ER} \beta$ and P-gp positive cells was done by using $\mathrm{ABC}$ staining system (Santa Cruz Biotechnology). Each slide was examined independently by two pathologists (from Jiangsu Cancer Hospital, Nanjing, Jiangsu, China) under a light microscope at $\times 400, \times 200$ and $\times 100$ magnification, and 10 randomly selected fields of view were obtained. Cytoplasm or nucleus staining intensity and pattern that reflect the levels of ER $\beta$, P-gp expressions were analyzed by using a composite score from 0 to $4+: 0$, completely negative; $1+$, faint positive for 
nuclear or cytosolic staining in $<24 \%$ of cells; $2+$, moderate positive staining covering between 25 to $49 \%$ of cells; $3+$, positive staining covering between 50 to $74 \%$ of cells; $4+$, strongly positive staining including $>75 \%$ cells.

Statistical analysis. The statistical significance of qRT-PCR results was analyzed using GraphPad Prism 7.0 (GraphPad Software, Inc., La Jolla, CA, USA). Student's t-test (2-group t-test) and one-way ANOVA were carried out for the two-group comparison and gene expression of separate subgroups at the mRNA expression level, respectively. All data are expressed as the mean \pm standard deviation.

To distinguish any differences in the distribution between high ER $\beta$ and P-gp from low expression groups, chi-squared tests or the Fisher's exact test for associations between ER $\beta$ and P-gp expression levels and clinicopathological data were performed [24]. The co-expression pattern of ER $\beta$ and P-gp were evaluated by the correspondence analysis and chi-squared tests. The threshold of $\mathrm{P}$ value was set as 0.05 to estimate the null hypothesis.

\section{Results}

Basic clinical and pathological data. A total of 152 NSCLC patients with relative clinical features (124 males and 28 females) were included (Table 2). The median age of the patients was 62.20 years (SD 8.85). 138 patients (90.8\%) were diagnosed with adenocarcinoma and 14 (9.2\%) with squamous cell carcinoma. Based on the eighth edition of the TNM classification of lung cancer from American Joint Committee on Cancer TNM staging system [25], among all the patients, there were 50 with tumor stage I (32.9\%), 47 with tumor stage II (30.9\%), 34 with tumor stage III (22.4\%) and 21 with tumor stage IV (13.8\%). Sixty-four (44.7\%) of the patients had lymph node metastasis.

mRNAs expressions of ER $\beta$ and MDR1 in NSCLC patients. To assess mRNA expression of ER $\beta$ and MDR1, patients were randomized into two groups (76 patients per group, Figure 1). The expression of two target genes was assessed at the mRNA level by qRT-PCR. ER $\beta$ mRNA expression ranged between 24.37 to 41.12 with a median of 31.39 . The expression range of MDR1 mRNA was 24.95-38.10, and the median was 31.09. In addition, we compared the mRNA expression of separate subgroups based on relative clinical features. Regarding the TNM staging classification, ER $\beta$ mRNA expression levels were significantly higher in patients with tumor stage I-II compared with advanced patients (Figure $2 \mathrm{~A})(\mathrm{p}<0.05)$. Other patient characteristics $(\mathrm{G} 1, \mathrm{G} 2$, G3) did not differ significantly in MDR1 and ER $\beta$ mRNA expression level (Figures 2B-2D).

Correlation between clinical features and expression of ER $\beta$ and P-gp. Immunohistochemistry was performed to investigate the expression pattern of ER $\beta$ and P-gp. Figure 3 demonstrates representative immunohistochemical staining of ER $\beta$ and P-gp in the nucleus and cytoplasm $(\times 200$ magnification). ER $\beta$ was mainly expressed in the nucleus and a
Table 2. Basic clinical characteristics of 152 NSCLC patients.

\begin{tabular}{|c|c|}
\hline Variables & No. of cases (\%) \\
\hline \multicolumn{2}{|l|}{ Gender } \\
\hline Female & $28(18.4 \%)$ \\
\hline Male & $124(81.6 \%)$ \\
\hline \multicolumn{2}{|l|}{ Age } \\
\hline$\leq 65$ years & $95(62.5 \%)$ \\
\hline$>65$ years & $57(37.5 \%)$ \\
\hline \multicolumn{2}{|l|}{ TNM } \\
\hline I & $50(32.9 \%)$ \\
\hline II & $47(30.9 \%)$ \\
\hline III & $34(22.4 \%)$ \\
\hline IV & $21(13.8 \%)$ \\
\hline \multicolumn{2}{|l|}{ T Stage } \\
\hline $\mathrm{T} 1$ & $50(32.9 \%)$ \\
\hline $\mathrm{T} 2$ & $81(53.3 \%)$ \\
\hline $\mathrm{T} 3$ & $17(11.2 \%)$ \\
\hline $\mathrm{T} 4$ & $4(2.6 \%)$ \\
\hline \multicolumn{2}{|l|}{ Lymph node metastases } \\
\hline No & $84(55.3 \%)$ \\
\hline N1 & $39(25.7 \%)$ \\
\hline $\mathrm{N} 2$ & $29(19.0 \%)$ \\
\hline \multicolumn{2}{|l|}{ Distant metastasis } \\
\hline M0 & $131(86.2 \%)$ \\
\hline M1 & $21(13.8 \%)$ \\
\hline \multicolumn{2}{|l|}{ Histologic Stage } \\
\hline G1 & $15(9.9 \%)$ \\
\hline G2 & $47(30.9 \%)$ \\
\hline G3 & $90(59.2 \%)$ \\
\hline \multicolumn{2}{|l|}{ Histology } \\
\hline Adenocarcinoma & $138(90.8 \%)$ \\
\hline Squamous cell carcinoma & $14(9.2 \%)$ \\
\hline
\end{tabular}

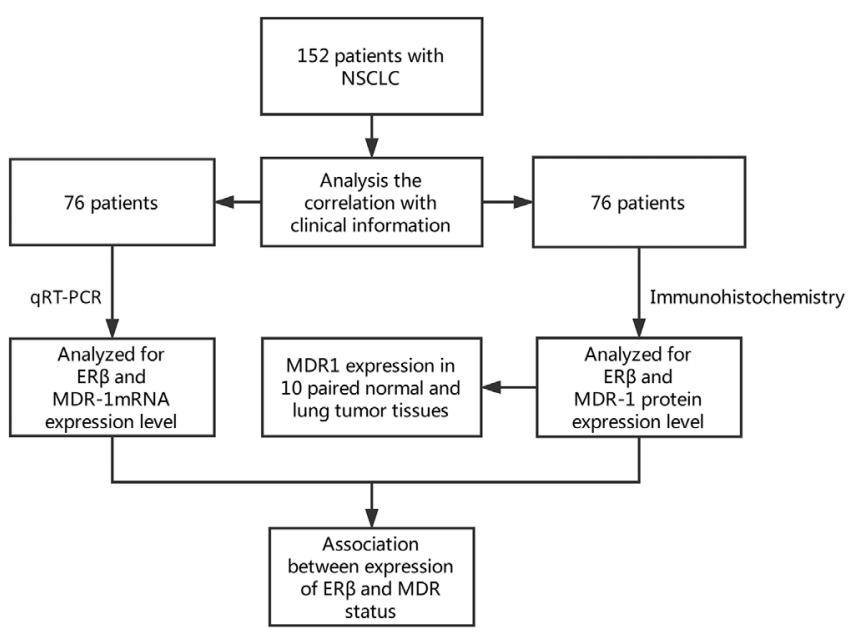

Figure 1. Flow chart of the analysis process. 


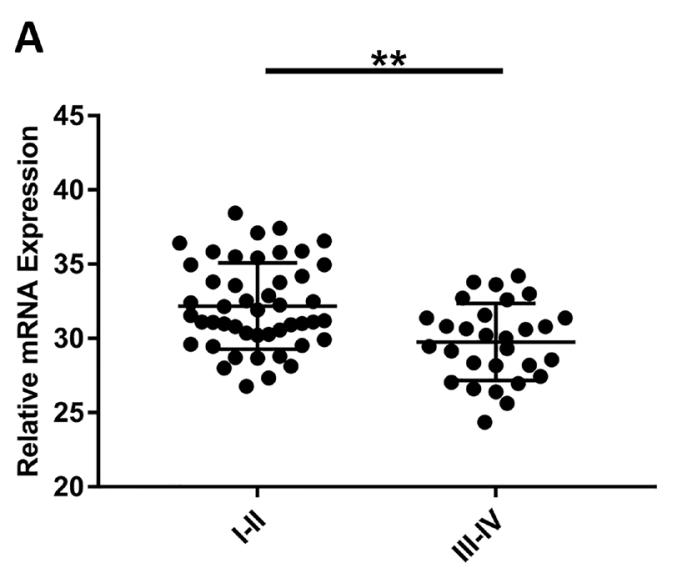

ER $\beta$

\section{C}

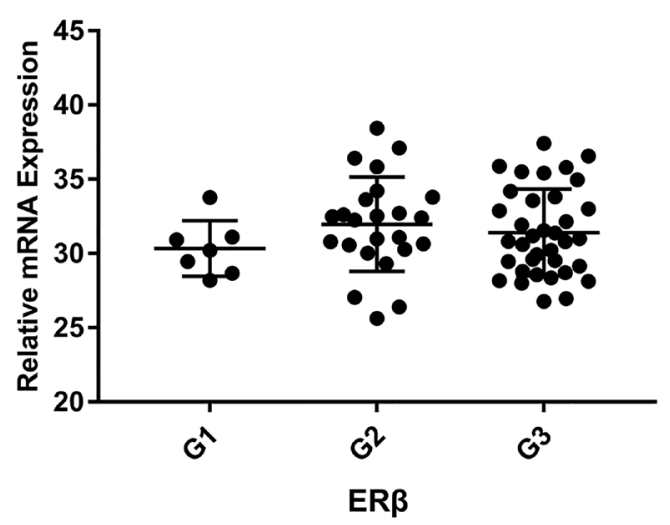

B

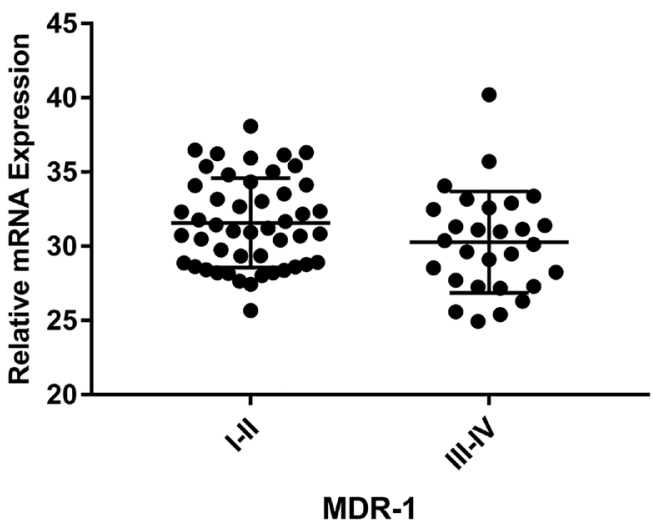

D

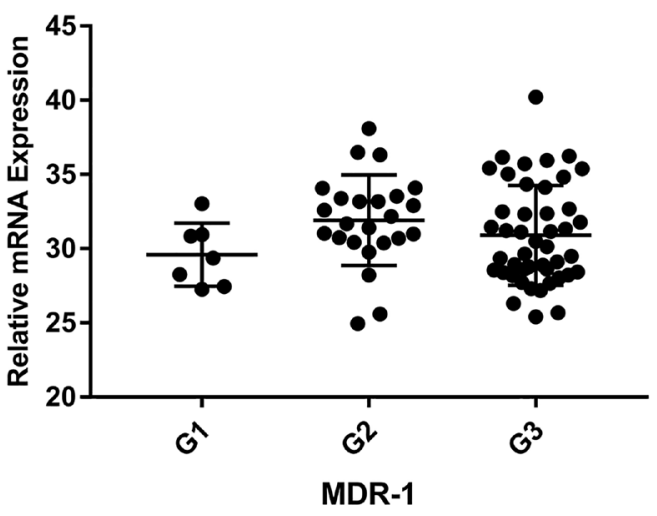

Figure 2. ER $\beta$ and MDR1 mRNA expression in NSCLC. A) Tumor tissue ER $\beta$ mRNA expression (I-II vs. III-IV); B) Tumor tissue MDR1 mRNA expression (I-II vs. III-IV); C) Tumor tissue ER $\beta$ mRNA expression (G1 vs. G2 vs. G3); D) Tumor tissue MDR1 mRNA expression (G1 vs. G2vs.S G3).

little part showed cytoplasmic localization, whereas P-gp staining was detected in the cytoplasm (Figure 3). A total of $61.8 \%$ (47/76) lung tumors were positive for nuclear ER $\beta$ expression, $89.5 \%$ (68/76) exhibited positive staining for cytoplasmic P-gp. Based on the expression status of ER $\beta$ (Negative or Positive), we analyzed the correlation between the two groups. There was no statistically significant difference in ER $\beta$ and P-gp expression associated with age, T Stage, lymph node metastases or distant metastasis status (Table 3). ER $\beta$ expression in patients with high tumor grade (G1, 87.5\%) was higher than that in middle (G2, 60.9\%) and low $(\mathrm{G} 3,60.0 \%)$ tumor grade $\left(\chi^{2}=10.421, \mathrm{p}=0.004\right)$. In ER $\beta$ expression, $87.5 \%$ of grade 1 tumors were found to be positive. The expression of ER $\beta$ was only positive in $60.9 \%$ of grade 2 and $60 \%$ of grade 3 tumors. The result was consistent with previous study showing that a higher percentage of early tumors expressed ER receptors [26]. In addition, Pearson Chi-square analysis revealed that P-gp expression was significantly higher in G3 tumors (97.8\%) compared with G1 (75.0\%) and G2 (78.3\%) (p<0.05) (Table 4).
To deeply investigate the correlation between $\operatorname{ER} \beta$ and MDR1 protein expression level and clinicopathological data, we divided the patients into two groups according to the score of immunohistochemistry results (low expression group: $1+, 2+$; high expression group: $3+, 4+$ ). However, no statistically significant differences were found between the high or low ER $\beta$ and P-gp expression groups in tumor grade, age, tumor stage, lymph node metastases, distant metastasis and histologic stage (Table 3, Table 4).

Increased expression of $\mathbf{P}$-gp in lung tumor tissues. To determine the role of P-gp expression in NSCLC, we performed immunohistochemistry on 10 pairs of samples consisting of both lung cancer tissues and adjacent normal lung tissue samples. In all samples, tumor tissues were MDR1-positive and three adjacent normal tissues were positive for P-gp staining. In lung tumor tissues we detected intracellular cytoplasmic localization of P-gp (Figure 4A). The IHC staining (composite score) showed a significantly increased expression of P-gp in NSCLC tissues compared to adjacent normal lung tissues (Figure 4B). Figure 5 shows the 

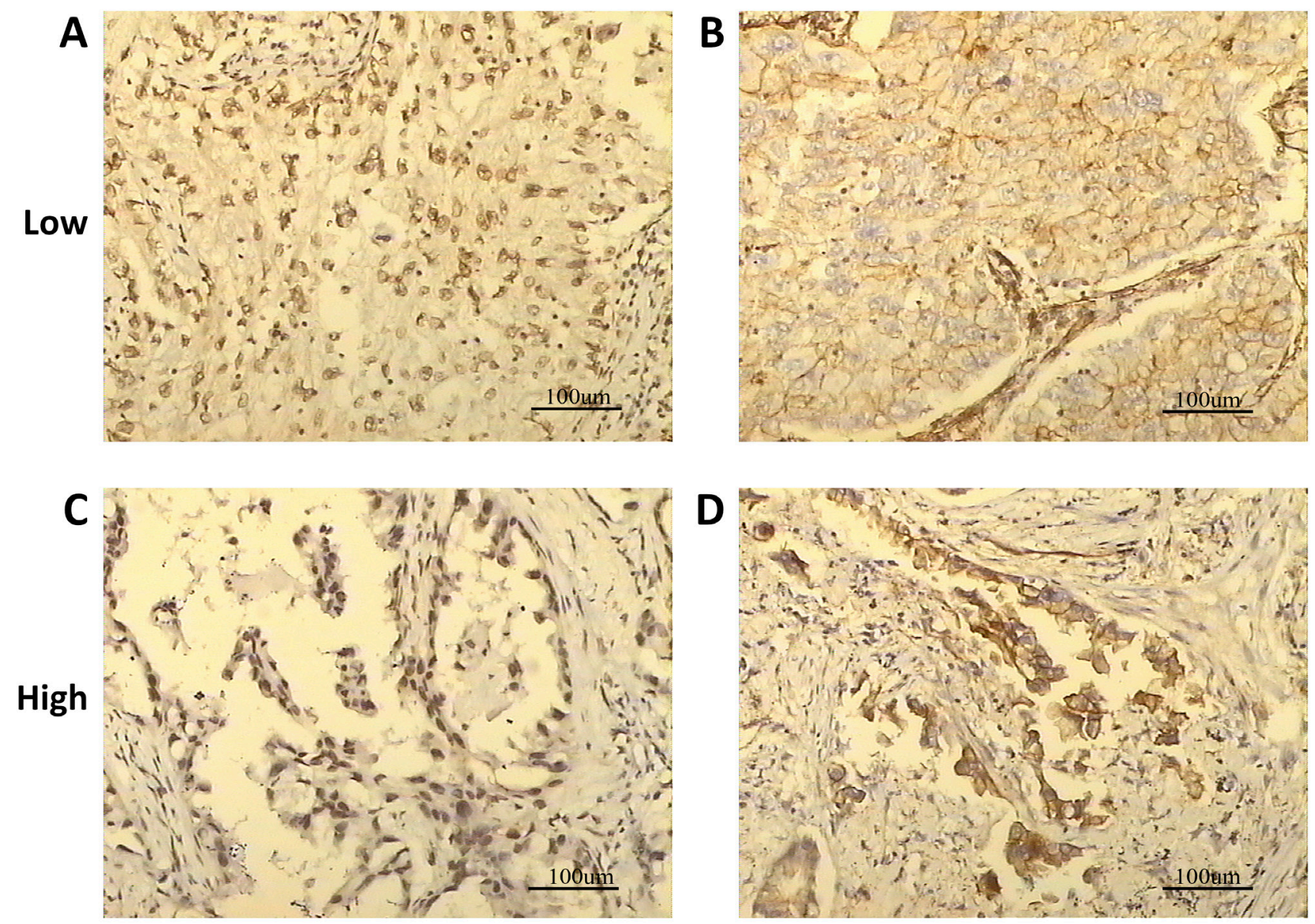

Figure 3. Immunohistochemical analysis of ER $\beta$ and MDR1 expression in NSCLC patients. Microscopic pictures at x 200 magnification, representing immunohistochemical staining of ER $\beta$ and P-gp expression. A) Tumor tissue ER $\beta$ low expression; B) Tumor tissue P-gp low expression; C) Tumor tissue ER $\beta$ high expression; D) Tumor tissue P-gp high expression.

different immunohistochemical expression level of P-gp in patients of NSCLC.

Correlation between ER $\beta$ and P-gp immunoreactivity. To further investigate the correlation between ER $\beta$ and P-gp, a correlation analysis was used to explore the association pattern between the ER $\beta$ and P-gp immunoreactivity levels $(1+, 2+, 3+, 4+)[27]$. The strength of association between each group could be interpreted as the distance separating two adjacent points. The smaller the distance, the greater the association between any particular group and other defined variables. Figure 6 showed that ER $\beta$ and P-gp were more closely related in the immunohistochemical high-level expression group $(2+, 3+$ and $4+)$.

Co-expression pattern of ER $\beta$ and individual P-gp were also assessed. The results indicated that a negative correlation between ER $\beta$ and P-gp was determined when P-gp low and P-gp high expression samples were compared. As shown in Table 3, in low P-gp expression group $(n=26)$, highly concomitant ER $\beta$ expression (92.3\%) was found in 24 tissue samples. However, in high P-gp expression group ( $\mathrm{n}=17)$, only 9 tissue samples were detected as high ER $\beta$ expression (52.9\%). Chi-squared test results showed statistically significant differences between the two groups $(\mathrm{p}<0.01)$.

\section{Discussion}

The human respiratory system is often exposed to environmental pathogens and environmental endocrine disruptors chemicals. One of the most important processes at the cellular level is the pumping of chemicals from cells by means of transporting protein systems at cell membranes [20]. Multidrug resistance (MDR) is a major obstacle to the efficacy of cancer chemotherapy. The drug transporter P-glycoprotein (P-gp) protein is considered to be the contributor to P-gpmediated multidrug resistance, encoded by the human multidrug resistance (MDR-1) gene [28]. The previous study has shown that ER $\alpha$ could increase expression of the MDR1 gene by directly activating gene transcription [29]. However, $E R \alpha$ and ER $\beta$ regulate gene expression in a classical and non-canonical way, inducing different biological responses 
Table 3. Correlations between tumor clinicopathological parameters and ER $\beta$ expression.

\begin{tabular}{|c|c|c|c|c|c|c|c|c|c|c|}
\hline \multirow[b]{2}{*}{ Variables } & \multicolumn{10}{|c|}{ ER $\beta$ expression } \\
\hline & Total & Negative & Positive & $\chi^{2}$ & p-value & Total & $\begin{array}{c}\text { Low } \\
(+ \text { to }++)\end{array}$ & $\begin{array}{c}\text { High } \\
(+++ \text { to }++++)\end{array}$ & $\chi^{2}$ & p-value \\
\hline \multicolumn{11}{|l|}{ Age } \\
\hline$\leq 65$ years & 51 & 20 & 31 & 0.375 & 0.617 & 31 & 4 & 27 & 4.969 & 0.051 \\
\hline$>65$ years & 25 & 8 & 17 & & & 17 & 5 & 12 & & \\
\hline \multicolumn{11}{|l|}{ Tumor Stage } \\
\hline I-II & 47 & 19 & 29 & 0.946 & 0.457 & 28 & 5 & 23 & 0.035 & 1.000 \\
\hline III-IV & 28 & 8 & 20 & & & 20 & 4 & 16 & & \\
\hline \multicolumn{11}{|l|}{ T Stage } \\
\hline $\mathrm{T} 1$ & 25 & 8 & 17 & 1.160 & 0.826 & 17 & 3 & 14 & 0.275 & 1.000 \\
\hline $\mathrm{T} 2$ & 39 & 14 & 25 & & & 25 & 5 & 20 & & \\
\hline $\mathrm{T} 3$ & 10 & 5 & 5 & & & 5 & 1 & 4 & & \\
\hline $\mathrm{T} 4$ & 2 & 1 & 1 & & & 1 & 0 & 1 & & \\
\hline \multicolumn{11}{|c|}{ Lymph node metastases } \\
\hline NO & 44 & 14 & 30 & 1.021 & 0.336 & 31 & 4 & 27 & 1.964 & 0.247 \\
\hline YES & 30 & 13 & 17 & & & 17 & 5 & 12 & & \\
\hline \multicolumn{11}{|c|}{ Distant metastasis } \\
\hline M0 & 62 & 26 & 36 & 3.752 & 0.068 & 36 & 7 & 29 & 0.046 & 1.000 \\
\hline M1 & 14 & 2 & 12 & & & 12 & 2 & 10 & & \\
\hline \multicolumn{11}{|l|}{ Tumor grade } \\
\hline G1 & 8 & 1 & 7 & 10.427 & 0.004 & 7 & 0 & 7 & 2.454 & 0.361 \\
\hline G2 & 23 & 9 & 14 & & & 31 & 6 & 25 & & \\
\hline G3 & 45 & 18 & 27 & & & 10 & 3 & 7 & & \\
\hline \multicolumn{11}{|l|}{ P-gp } \\
\hline Negative & 6 & 4 & 4 & 0.665 & 0.457 & & & & & \\
\hline Positive & 68 & 24 & 44 & & & & & & & \\
\hline Low & & & & & & 26 & 2 & 24 & 8.925 & 0.004 \\
\hline High & & & & & & 17 & 8 & 9 & & \\
\hline
\end{tabular}

A

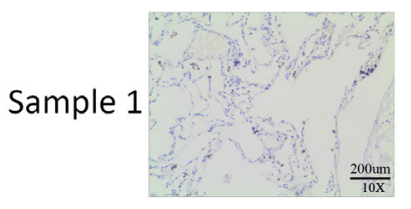

Sample 2
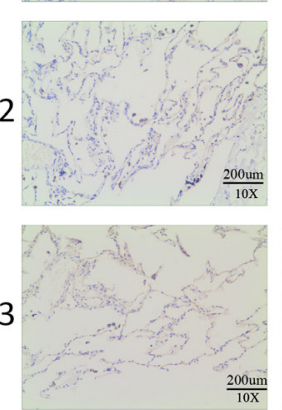

Normal
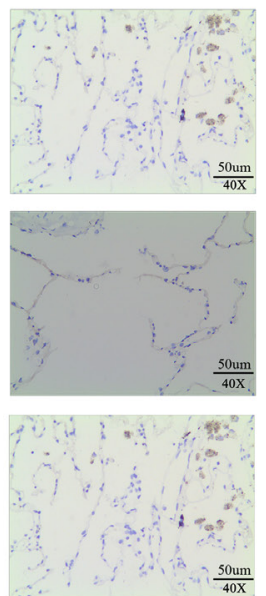

Tumor tissue
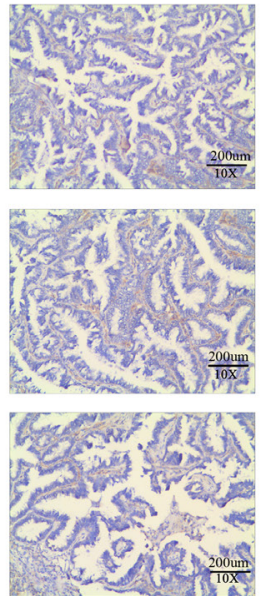

B

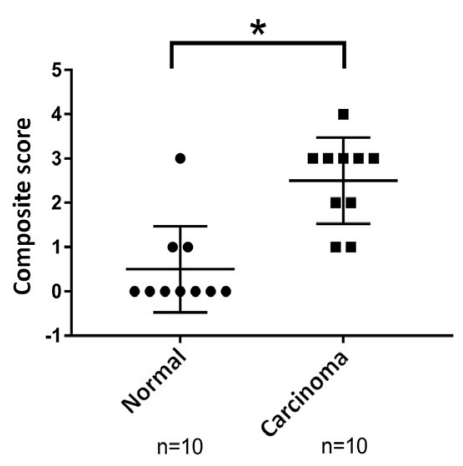

Figure 4. Expression of P-gp in lung cancer tissues and adjacent normal lung tissue samples. A) Immunohistochemical staining of tissues using P-gp antibody in both normal and lung tumor tissues. B) Graphical representation of the IHC composite score of each tissue sample. The composite score was calculated for each sample using the percentage of cells positive for P-gp staining. The graph was plotted using the composite score and p-values were calculated using 2-group t-test ( $p<0.05$ considered as significant). 
Table 4. Correlations between tumor clinicopathological parameters and P-gp expression.

\begin{tabular}{|c|c|c|c|c|c|c|c|c|c|c|}
\hline \multirow[b]{2}{*}{ Variables } & \multicolumn{10}{|c|}{ MDR1 expression } \\
\hline & Total & Negative & Positive & $\chi^{2}$ & p-value & Total & $\begin{array}{c}\text { Low } \\
(+ \text { to }++)\end{array}$ & $\begin{array}{c}\text { High } \\
(+++ \text { to }++++)\end{array}$ & $\chi^{2}$ & p-value \\
\hline \multicolumn{11}{|l|}{ Age } \\
\hline$\leq 65$ years & 51 & 7 & 44 & 1.685 & 0.259 & 44 & 26 & 18 & 0.154 & 0.799 \\
\hline$>65$ years & 25 & 1 & 24 & & & 24 & 13 & 11 & & \\
\hline \multicolumn{11}{|l|}{ Tumor Stage } \\
\hline I-II & 49 & 7 & 42 & 0.789 & 0.478 & 42 & 25 & 17 & 0.212 & 0.801 \\
\hline III-IV & 27 & 2 & 25 & & & 26 & 14 & 12 & & \\
\hline \multicolumn{11}{|l|}{ T Stage } \\
\hline $\mathrm{T} 1$ & 25 & 3 & 22 & 0.338 & 1.000 & 22 & 9 & 13 & 4.844 & 0.199 \\
\hline $\mathrm{T} 2$ & 39 & 5 & 34 & & & 34 & 21 & 13 & & \\
\hline T3 & 10 & 1 & 9 & & & 10 & 8 & 2 & & \\
\hline $\mathrm{T} 4$ & 2 & 0 & 2 & & & 2 & 1 & 1 & & \\
\hline \multicolumn{11}{|c|}{ Lymph node metastases } \\
\hline NO & 42 & 3 & 39 & 1.414 & 0.455 & 39 & 26 & 13 & 3.243 & 0.087 \\
\hline YES & 34 & 5 & 29 & & & 29 & 13 & 16 & & \\
\hline \multicolumn{11}{|c|}{ Distant metastasis } \\
\hline M0 & 62 & 7 & 55 & 0.209 & 1.000 & 55 & 30 & 25 & 0.927 & 0.372 \\
\hline M1 & 14 & 1 & 13 & & & 13 & 9 & 4 & & \\
\hline \multicolumn{11}{|l|}{ Tumor grade } \\
\hline G1 & 8 & 2 & 6 & 8.415 & 0.018 & 6 & 5 & 1 & 2.224 & 0.330 \\
\hline G2 & 23 & 5 & 18 & & & 18 & 11 & 7 & & \\
\hline G3 & 45 & 1 & 44 & & & 44 & 23 & 21 & & \\
\hline
\end{tabular}
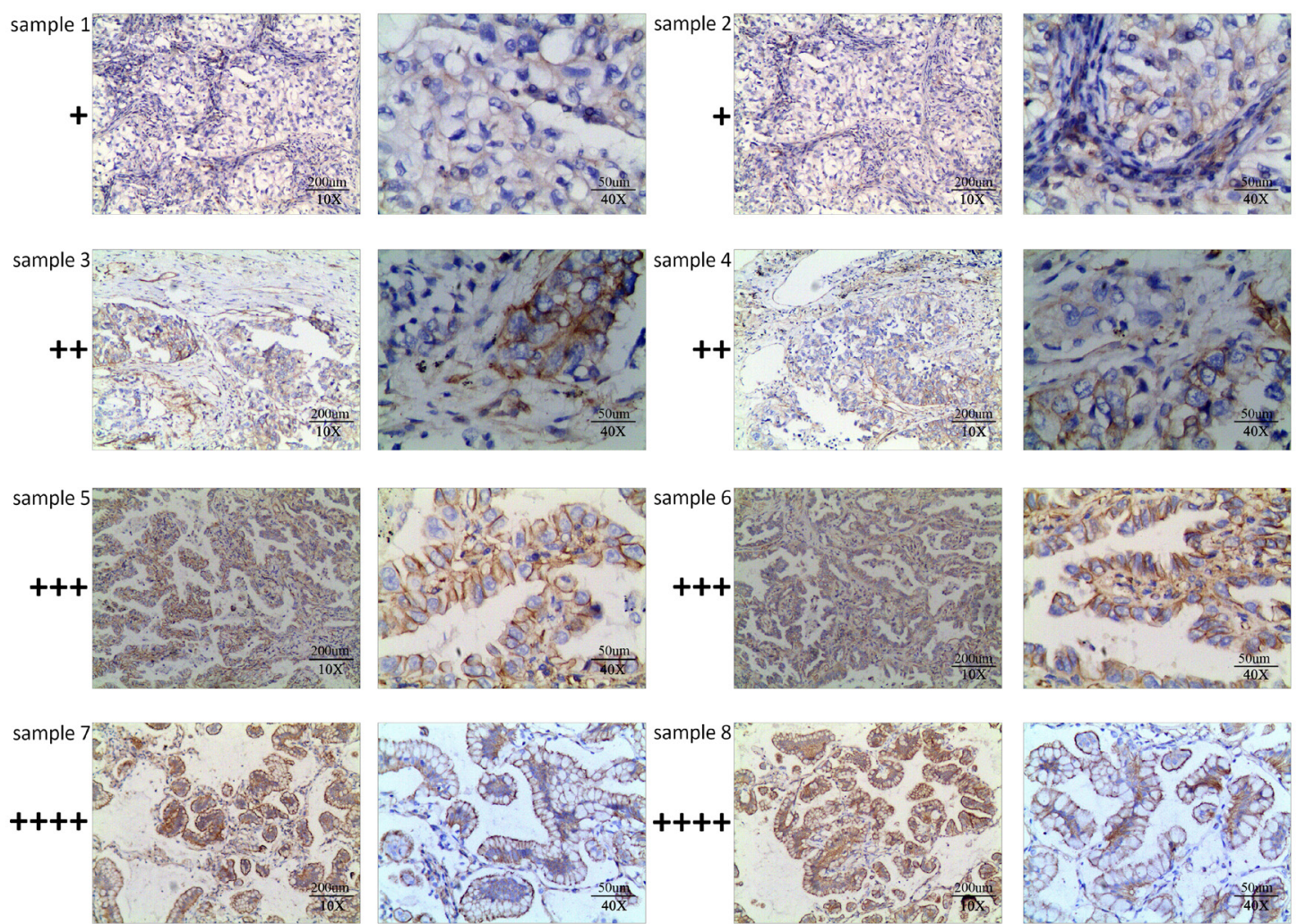

Figure 5. Representative immunohistochemical staining of P-gp in NSCLC tissue. All images were captured at magnification $\times 100$ and $\times 400$. P-gp expressions were analyzed by using a composite score from 0 to $4+$ : 0 , completely negative; $1+$, faint positive for nuclear or cytosolic staining in $<24 \%$ of cells; $2+$, moderate positive staining covering between 25 to $49 \%$ of cells; $3+$, positive staining covering between 50 to $74 \%$ of cells; $4+$, strongly positive staining including $>75 \%$ cells. 
[30]. Interestingly, Lindberg et al. have reported a "ying-yang" relationship between $\mathrm{ER} \alpha$ and $\mathrm{ER} \beta$, and also found that $\mathrm{ER} \beta$ is associated with antiproliferative effects [31]. The study of the link between the ER $\beta$ and MDR1 genes is drawing more attention, but it is still equivocal. Our specific aim was to explore the association of ER $\beta$ and MDR1 and to determine its correlation with clinicopathological parameters including age, TNM stage, T Stage, tumor grade, lymph node metastases or distant metastasis status. To delineate the expression patterns of ER $\beta$ and MDR1, we analyzed qRT-PCR and immunohistochemistry results in 152 patients with NSCLC.

We demonstrated that mRNA expression of $\operatorname{ER} \beta$ was significantly associated with TNM stage, and patients with tumor stage I-II showed higher levels of ER $\beta$ mRNA expression (Figure 2). As the tumor stage progresses, the expression level of ER $\beta$ gradually decreases. Commensurate with previous reports, studies of breast cancer cell lines documented a decrease in ER $\beta$ expression during tumorigenesis [32,33]. Unlike ER $\alpha$, it is generally accepted that ER $\beta$ has a markedly different role and is considered to function as a tumor suppressor [34]. Mauro et al. determined that the lack of nuclear ERß was associated with poor prognosis in NSCLC patients [26]. Studies on gliomas also proved that declined expression of ER $\beta$ may be involved in the tumorigenesis, and its presence decreases with increased malignancy $[35,36]$.

According to reports, ERs are functional both at nuclear and extranuclear locations. We mainly detected ER $\beta$ expression at nuclear localization in NSCLC samples. ER $\beta$ and MDR1 (P-gp) expressions were detected in 47 (61.8\%) and $68(89.5 \%)$ out of 76 samples of NSCLC, respectively.

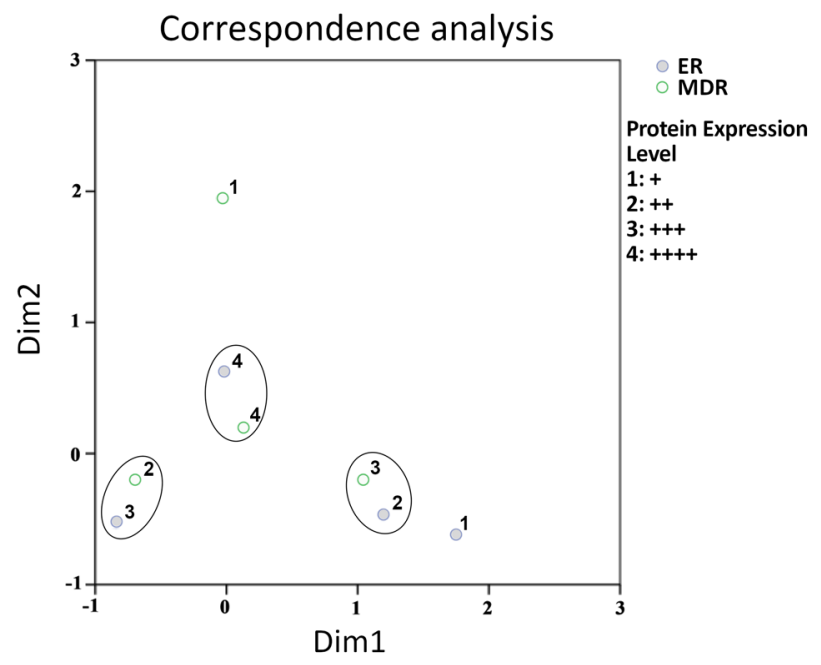

Figure 6. Correspondence analysis of the pattern of association between levels of $E R \beta$ and MDR1 immunoreactivity of NSCLC tissue samples. The strength of association between each group and level of immunoreactivity together can easily be interpreted in relation to the distance separating two adjacent points. The smaller the distance, the greater association there is between any specific groups.
More importantly, we found a negative correlation between ER $\beta$ protein expression and tumor grade. In grade 1 tumors, $7 / 8(87.5 \%)$ tumors sample showed positive expression of $\mathrm{ER} \beta$. The positive expression rate of $\mathrm{ER} \beta$ is progressively decreased in grade 2 and 3 tumors. Our results correlate well with previously studies in which ERs expression are correlated inversely with tumor grade and TNM stage in breast cancer [37]. Batistatou et al. reported that ER $\beta$ expression tends to decrease with increased histological malignancy of the tumor [38]. Although the therapeutic significance of ER $\beta$ signaling in lung cancer remains elusive, the current studies on the significance of expression and prognosis suggests that nuclear ER $\beta$ predicts better survival outcomes [26, 39-42].

Previous data suggest that P-gp expression in lung cancer is initially small but variable, and increases with disease progression and acquired resistance to cancer chemotherapy [19]. Similarly, we found that P-gp expression in NSCLC was positively correlated with tumor grade (Table 4 ), which is contrary to the expression trend of ER $\beta$. In addition, studies have shown that P-gp expression is positively correlated with the invasion potential of tumor cells $[43,44]$. The current results showed no significant differences in other clinical features between the ER $\beta$ and P-gp expression groups (Table 3, Table 4).

Although P-gp is associated with advanced cancer and drug failure, clinical validation trials for P-gp or other ABC (ATP-binding cassette) transporters are rarely established [45]. In addition, some studies showed that over-expression of P-gp is associated with MDR in different types of cancer, leading to poor patient prognosis [46-48]. We also demonstrated that increased expression of P-gp in lung tumor tissues (Figure 4) compared with adjacent non-tumor tissues, consistent with previous reports [49-51]. It is worth noting that some studies have correlated P-gp overexpression with negative survival outcomes, including treatment failure and relapse [52-54].

Researches have previously reported that estrogens inhibit breast cancer resistance protein (BCRP)-mediated drug resistance, which subsequently indicates that the estrogen sulfate conjugate is the physiological substrate of BCRP [55-58]. To date, there is evidence that ER $\alpha$ could directly regulate the expression of the MDR1 gene [29, 59]. However, only a few studies have used population-based cases and few have evaluated differences in ER $\beta$ expression by subject characteristics or association with MDR1 in NSCLC patients. Therefore, we evaluated the correlation between the levels of immunoreactivity of ER $\beta$ and P-gp based on the same patient. Correspondence analysis showed that ER $\beta$ and MDR1 were closely related in higher level of immunohistochemical expression (Figure 6). Next, we also explored the co-expression of ER $\beta$ and individual MDR1 protein (P-gp). The results showed a negative correlation between $\mathrm{ER} \beta$ and MDR1 protein when MDR1 low and MDR1 high samples are compared (Table 3). Taken together, our analysis suggests that a decrease of ER $\beta$ in advanced NSCLC patients might lead to a gradual increase in MDR1 expression. 
In conclusion, our data demonstrate the expression pattern of ER $\beta$ and MDR1 in NSCLC. We believe that the most important finding in this study is that as the tumor grade increases, the expression of ER $\beta$ gradually decreases which is contrary to the expression of MDR1, and the loss of ER $\beta$ can be explained by the progressive dedifferentiation of tumor cells. In addition, an opposite co-expression pattern of ER $\beta$ and individual MDR1 proteins was also observed. Despite some speculative explanations of this fact by the possible regulation of MDR1 expression through ERs. These results can be used to better understand the expression control of MDR1 and may allow for the establishment of new cancer chemistry strategies that will control P-gp expression in NSCLC, thereby increasing their sensitivity to MDR1-related anticancer agents.

The results of this study may have potential clinical significance, but it cannot be ignored that some limitations should be taken into consideration in this study. The influence of the single gene on the malignant biological behavior of NSCLC is affected by many kinds of uncertain factors, thus in vivo and in vitro experiments to explore the specific functions and molecular mechanism should be accomplished in the further study. Further evidence of the direct targeting regulatory relationship between $\mathrm{ER} \beta$ and MDR1 is needed.

Acknowledgments: The present study was supported by the National Natural Science Foundation of China (81872191 and 81972998) and the Postgraduate Research \& Practice Innovation Program of Jiangsu Province (KYCX19_0120). Natural Science Foundation of Jiangsu province (BK20161597), Social Development Foundation of Jiangsu province (BE2017760) and the Natural Science Foundation of Jiangxi, China (grant no. 20142BAB205017) and the Science and Technology Program of Jiangxi Provincial Health Department (grant no. GJJ14719).

\section{References}

[1] IQBAL MA, ARORA S, PRAKASAM G, CALIN GA, SYED MA. MicroRNA in lung cancer: Role, mechanisms, pathways and therapeutic relevance. Mol Aspects Med 2018. https:// doi.org/10.1016/j.mam.2018.07.003

[2] SIEGEL RL, MILLER KD, JEMAL A. Cancer statistics, 2018. CA Cancer J Clin 2018; 68: 7-30. https://doi.org/10.3322/ caac. 21442

[3] CHEN W, ZHENG R, BAADE PD, ZHANG S, ZENG H et al. Cancer statistics in China, 2015. CA Cancer J Clin 2016; 66: 115-132. https://doi.org/10.3322/caac.21338

[4] TORRE LA, SIEGEL RL, JEMAL A. Lung Cancer Statistics. Adv Exp Med Biol 2016; 893: 1-19. https://doi. org/10.1007/978-3-319-24223-1_1

[5] ALBERG AJ, BROCK MV, FORD JG, SAMET JM, SPIVACK SD. Epidemiology of lung cancer: Diagnosis and management of lung cancer, 3rd ed: American College of Chest Physicians evidence-based clinical practice guidelines. Chest 2013; 143: e1S-e29S. https://doi.org/10.1378/chest.12-2345
[6] SAGERUP CM, SMASTUEN M, JOHANNESEN TB, HELLAND A, BRUSTUGUN OT. Sex-specific trends in lung cancer incidence and survival: a population study of 40,118 cases. Thorax 2011; 66: 301-307. https://doi.org/10.1136/ thx.2010.151621

[7] WAKELEE HA, WANG W, SCHILLER JH, LANGER CJ, SANDLER AB et al. Survival differences by sex for patients with advanced non-small cell lung cancer on Eastern Cooperative Oncology Group trial 1594. J Thorac Oncol 2006; 1: 441-446.

[8] SCARANO WR, PINHO CF, PISSINATTI L, GONÇALVES BF, MENDES LO et al. Cell junctions in the prostate: an overview about the effects of Endocrine Disrupting Chemicals (EDCS) in different experimental models. Reprod Toxicol 2018; 81: 147-154. https://doi.org/10.1016/j. reprotox.2018.08.009

[9] XU Z, YANG Z, LIU Z. Development of dual-templates molecularly imprinted stir bar sorptive extraction and its application for the analysis of environmental estrogens in water and plastic samples. J Chromatogr A 2014; 1358: 52-59. https://doi.org/10.1016/j.chroma.2014.06.093

[10] PROSSNITZ ER, ARTERBURN JB, SMITH HO, OPREA TI, SKLAR LA et al. Estrogen signaling through the transmembrane G protein-coupled receptor GPR30. Ann Rev Physiol 2008; 70: 165-190. https://doi.org/10.1146/annurev. physiol.70.113006.100518

[11] CARREAU S, BOURAIMA-LELONG H, DELALANDE C. Estrogen, a female hormone involved in spermatogenesis. Adv Med Sci 2012; 57: 31-36. https://doi.org/10.2478/ v10039-012-0005-y

[12] TOWNSON SM, O'CONNELL P. Identification of estrogen receptor alpha variants in breast tumors: implications for predicting response to hormonal therapies. J Surg Oncol 2006; 94: 271-273. https://doi.org/10.1002/jso.20589

[13] CAVALIERI E, FRENKEL K, LIEHR JG, ROGAN E, ROY D. Estrogens as endogenous genotoxic agents--DNA adducts and mutations. J Natl Cancer Inst Monogr 2000; 75-93. https://doi.org/10.1093/oxfordjournals.jncimonographs. a024247

[14] SIEGFRIED JM, STABILE LP. Estrongenic steroid hormones in lung cancer. Semin Oncol 2014; 41: 5-16. https:// doi.org/10.1053/j.seminoncol.2013.12.009

[15] MONICA V, LONGO M, FELICE B, SCAGLIOTTI GV, PAPOTTI $M$ et al. Role of hormone receptor expression in patients with advanced-stage lung cancer treated with chemotherapy. Clin Lung Cancer 2012; 13: 416-423. https://doi. org/10.1016/j.cllc.2012.03.006

[16] VERMA MK, MIKI Y, ABE K, NAGASAKI S, NIIKAWA $\mathrm{H}$ et al. Co-expression of estrogen receptor beta and aromatase in Japanese lung cancer patients: gender-dependent clinical outcome. Life Sci 2012; 91: 800-808. https://doi. org/10.1016/j.lfs.2012.08.029

[17] Y. LIU, M. INOUE, T. SOBUE, S. TSUGANE. Reproductive factors, hormone use and the risk of lung cancer among middle-aged never-smoking Japanese women: a large-scale population-based cohort study. Int J Cancer 2005; 117: 662666. https://doi.org/10.1002/ijc.21229 
[18] CHLEBOWSKI RT, SCHWARTZ AG, WAKELEE H, ANDERSON GL, STEFANICK ML et al. Oestrogen plus progestin and lung cancer in postmenopausal women (Women's Health Initiative trial): a post-hoc analysis of a randomised controlled trial. Lancet 2009; 374: 1243-1251. https://doi. org/10.1016/S0140-6736(09)61526-9

[19] YU H, XU Z, CHEN X, XU L, YIN Q et al. Reversal of lung cancer multidrug resistance by $\mathrm{pH}$-responsive micelleplexes mediating co-delivery of siRNA and paclitaxel. Macromol Biosci 2014; 14: 100-109. https://doi.org/10.1002/ mabi.201300282

[20] MILOJKOVIC M, MILACIC N, RADOVIC J, LJUBISAVLJEVIC S. MDR1 gene polymorphisms and P-glycoprotein expression in respiratory diseases. Biomed Pap Med Fac Univ Palacky Olomouc Czech Repub 2015; 159: 341-346. https://doi.org/10.5507/bp.2014.032

[21] SCHEFFER GL, PIJNENBORG AC, SMIT EF, MÜLLER M, POSTMA DS et al. Multidrug resistance related molecules in human and murine lung. J Clin Pathol 2002; 55: 332-339. https://doi.org/10.1136/jcp.55.5.332

[22] XU L, LEI J, JIANG D, ZHOU L, WANG S et al. Reversal effects of Raloxifene on paclitaxel resistance in 2 MDR breast cancer cells. Cancer Biol Ther 2015; 16: 1794-1801. https:// doi.org/10.1080/15384047.2015.1095409

[23] ATMACA A, AL-BATRAN SE, WIRTZ RM, WERNER D, ZIRLIK $S$ et al. The validation of estrogen receptor $1 \mathrm{mRNA}$ expression as a predictor of outcome in patients with metastatic non-small cell lung cancer. Int J Cancer 2014; 134: 2314-2321. https://doi.org/10.1002/ijc.28571

[24] BRUECKL WM, AL-BATRAN SE, FICKER JH, CLAAS S, ATMACA A et al. Prognostic and predictive value of estrogen receptor 1 expression in completely resected non-small cell lung cancer. Int J Cancer 2013; 133: 1825-1831. https:// doi.org/10.1002/ijc.28209

[25] RAMI-PORTA R, BOLEJACK V, GIROUX DJ, CHANSKY $\mathrm{K}, \mathrm{CROWLEY} \mathrm{J}$ et al. The IASLC lung cancer staging project: the new database to inform the eighth edition of the TNM classification of lung cancer. J Thorac Oncol 2014; 9: 16181624. https://doi.org/10.1097/JTO.0000000000000334

[26] MAURO LV, DALURZO M, CARLINI MJ, SMITH D, NUNEZ $M$ et al. Estrogen receptor beta and epidermal growth factor receptor as early-stage prognostic biomarkers of non-small cell lung cancer. Oncol Rep 2010;24: 1331-1338.

[27] RODRIGUEZ-LARA V, PENA-MIRABAL E, BAEZ-SALDANA R, ESPARZA-SILVA AL, GARCIA-ZEPEDA E et al. Estrogen receptor beta and CXCR4/CXCL12 expression: differences by sex and hormonal status in lung adenocarcinoma. Arch Med Res 2014; 45: 158-169. https://doi.org/10.1016/j. arcmed.2014.01.001

[28] YAMAGISHI T, SAHNI S, SHARP DM, ARVIND A, JANSSON PJ et al. P-glycoprotein mediates drug resistance via a novel mechanism involving lysosomal sequestration. J Biol Chem 2013; 288: 31761-31771. https://doi.org/10.1074/jbc. M113.514091

[29] SHI JF, YANG N, DING HJ, ZHANG JX, HU ML et al. ERalpha directly activated the MDR1 transcription to increase paclitaxel-resistance of ERalpha-positive breast cancer cells in vitro and in vivo. Int J Biochem Cell Biol 2014; 53: 35-45. https://doi.org/10.1016/j.biocel.2014.04.016
[30] SCOBIE GA, MACPHERSON S, MILLAR MR, GROOME NP, ROMANA PG et al. Human oestrogen receptors: differential expression of ER alpha and beta and the identification of ER beta variants. Steroids 2002; 67: 985-992. https://doi. org/10.1016/S0039-128X(02)00047-8

[31] LINDBERG MK, MOVERARE S, SKRTIC S, GAO H, DAHLMAN-WRIGHT K et al. Estrogen receptor (ER)-beta reduces ERalpha-regulated gene transcription, supporting a "ying yang" relationship between ERalpha and ERbeta in mice. Mol Endocrinol 2003; 17: 203-208. https://doi. org/10.1210/me.2002-0206

[32] BRANDENBERGER AW, TEE MK, JAFFE RB. Estrogen receptor alpha (ER-alpha) and beta (ER-beta) mRNAs in normal ovary, ovarian serous cystadenocarcinoma and ovarian cancer cell lines: down-regulation of ER-beta in neoplastic tissues. J Clin Endocrinol Metab 1998; 83: 1025-1028. https://doi.org/10.1210/jcem.83.3.4788

[33] HARTMAN J, STROM A, GUSTAFSSON JA. Estrogen receptor beta in breast cancer--diagnostic and therapeutic implications. Steroids 2009; 74: 635-641. https://doi. org/10.1016/j.steroids.2009.02.005

[34] NILSSON S, GUSTAFSSON JA. Estrogen receptors: therapies targeted to receptor subtypes. Clin Pharmacol Ther 2011; 89: 44-55. https://doi.org/10.1038/clpt.2010.22

[35] BATISTATOU A, STEFANOU D, GOUSSIA A, ARKOUMANI E, PAPAVASSILIOU AG et al. Estrogen receptor beta (ERbeta) is expressed in brain astrocytic tumors and declines with dedifferentiation of the neoplasm. J Cancer Res Clin Oncol 2004; 130: 405-410. https://doi.org/10.1007/s00432004-0548-9

[36] LIU C, ZHANG Y, ZHANG K, BIAN C, ZHAO Y et al. Expression of estrogen receptors, androgen receptor and steroid receptor coactivator-3 is negatively correlated to the differentiation of astrocytic tumors. Cancer Epidemiol 2014; 38: 291-297. https://doi.org/10.1016/j.canep.2014.03.001

[37] RYBAROVA S, HODOROVA I, HAJDUKOVA M, SCHMIDTOVA K, MOJZIS J et al. Expression of MDR proteins in breast cancer and its correlation with some clinical and pathological parameters. Neoplasma 2006; 53: 128-135.

[38] BATISTATOU A, KYZAS PA, GOUSSIA A, ARKOUMANI E, VOULGARIS $S$ et al. Estrogen receptor beta (ERbeta) protein expression correlates with BAG-1 and prognosis in brain glial tumours. J Neurooncol 2006; 77: 17-23. https:// doi.org/10.1007/s11060-005-9005-0

[39] BAIK CS, EATON KD. Estrogen signaling in lung cancer: an opportunity for novel therapy. Cancers (Basel) 2012; 4: 969-988. https://doi.org/10.3390/cancers4040969

[40] WU CT, CHANG YL, SHIH JY, LEE YC. The significance of estrogen receptor beta in 301 surgically treated non-small cell lung cancers. J Thorac Cardiovasc Surg 2005; 130: 979_ 986. https://doi.org/10.1016/j.jtcvs.2005.06.012

[41] SKOV BG, FISCHER BM, PAPPOT H. Oestrogen receptor beta over expression in males with non-small cell lung cancer is associated with better survival. Lung Cancer 2008; 59: 88-94. https://doi.org/10.1016/j.lungcan.2007.07.025 
[42] SCHWARTZ AG, PRYSAK GM, MURPHY V, LONARDO F, PASS $\mathrm{H}$ et al. Nuclear estrogen receptor beta in lung cancer: expression and survival differences by sex. Clin Cancer Res 2005; 11: 7280-7287. https://doi.org/10.1158/1078-0432. CCR-05-0498

[43] LESLIE EM, DEELEY RG, COLE SP. Multidrug resistance proteins: role of P-glycoprotein, MRP1, MRP2, and BCRP (ABCG2) in tissue defense. Toxicol Appl Pharmacol 2005; 204: 216-237. https://doi.org/10.1016/j.taap.2004.10.012

[44] BEER TW, ROWLANDS DC, CROCKER J. Detection of the multidrug resistance marker P-glycoprotein by immunohistochemistry in malignant lung tumours. Thorax 1996; 51: 526-529. https://doi.org/10.1136/thx.51.5.526

[45] TAMAKI A, IERANO C, SZAKACS G, ROBEY RW, BATES SE. The controversial role of $\mathrm{ABC}$ transporters in clinical oncology. Essays Biochem 2011; 50: 209-232. https://doi. org/10.1042/bse0500209

[46] SANCHEZ C, MERCADO A, CONTRERAS HR, MENDOZA P, CABEZAS J et al. Chemotherapy sensitivity recovery of prostate cancer cells by functional inhibition and knock down of multidrug resistance proteins. Prostate 2011; 71: 1810-1817. https://doi.org/10.1002/pros.21398

[47] SHAROM FJ. ABC multidrug transporters: structure, function and role in chemoresistance. Pharmacogenomics 2008; 9: 105-127. https://doi.org/10.2217/14622416.9.1.105

[48] MUNOZ M, HENDERSON M, HABER M, NORRIS M. Role of the MRP1/ABCC1 multidrug transporter protein in cancer. IUBMB Life 2007; 59: 752-757. https://doi. org/10.1080/15216540701736285

[49] TRUSSARDI-REGNIER A, MILLOT JM, GORISSE MC, DELVINCOURT C, PREVOST A. Detection of drug-resistance genes using single bronchoscopy biopsy specimens. Oncol Rep 2007; 18: 703-708.

[50] LU Y, YU LQ, ZHU L, ZHAO N, ZHOU XJ et al. Expression of HIF-1alpha and P-gp in non-small cell lung cancer and the relationship with HPV infection. Oncol Lett 2016; 12: 1455-1459. https://doi.org/10.3892/ol.2016.4751

[51] SEEBACHER N, LANE DJ, RICHARDSON DR, JANSSON PJ. Turning the gun on cancer: Utilizing lysosomal P-glycoprotein as a new strategy to overcome multi-drug resistance. Free Radic Biol Med 2016; 96: 432-445. https://doi. org/10.1016/j.freeradbiomed.2016.04.201
[52] PALLIS M, TURZANSKI J, HIGASHI Y, RUSSELL N. P-glycoprotein in acute myeloid leukaemia: therapeutic implications of its association with both a multidrug-resistant and an apoptosis-resistant phenotype. Leuk Lymphoma 2002; 43: 1221-1228. https:/doi. org/10.1080/10428190290026277

[53] RASPADORI D, DAMIANI D, MICHIELI M, STOCCHI R, GENTILI $S$ et al. CD56 and PGP expression in acute myeloid leukemia: impact on clinical outcome. Haematologica 2002; 87: 1135-1140.

[54] SCHAICH M, SOUCEK S, THIEDE C, EHNINGER G, ILLMER T et al. MDR1 and MRP1 gene expression are independent predictors for treatment outcome in adult acute myeloid leukaemia. Br J Haematol 2005; 128: 324-332. https:// doi.org/10.1111/j.1365-2141.2004.05319.x

[55] IMAI Y, TSUKAHARA S, ISHIKAWA E, TSURUO T, SUGIMOTO Y. Estrone and 17beta-estradiol reverse breast cancer resistance protein-mediated multidrug resistance. Jpn J Cancer Res 2002; 93: 231-235. https://doi. org/10.1111/j.1349-7006.2002.tb02162.x

[56] SUGIMOTO Y, TSUKAHARA S, IMAI Y, SUGIMOTO Y, UEDA K et al. Reversal of breast cancer resistance proteinmediated drug resistance by estrogen antagonists and agonists. Mol Cancer Ther 2003; 2: 105-112.

[57] SUZUKI M, SUZUKI H, SUGIMOTO Y, SUGIYAMA Y. ABCG2 transports sulfated conjugates of steroids and xenobiotics. J Biol Chem 2003; 278: 22644-22649. https://doi. org/10.1074/jbc.M212399200

[58] IMAI Y, ASADA S, TSUKAHARA S, ISHIKAWA E, TSURUO $\mathrm{T}$ et al. Breast cancer resistance protein exports sulfated estrogens but not free estrogens. Mol Pharmacol 2003; 64: 610-618. https://doi.org/10.1124/mol.64.3.610

[59] CHEN S, WANG H, LI Z, YOU J, WU QW et al. Interaction of WBP2 with ERa increases doxorubicin resistance of breast cancer cells by modulating MDR1 transcription. $\mathrm{Br}$ J Cancer 2018: 182-192. https://doi.org/10.1038/s41416018-0119-5 